\title{
Studying the Category of Femininity by Iranian Students
}

\section{Sannikova Nataliya Yurevna ${ }^{1}$}

Associate professor, Astrakhan State University,

\author{
Astrakhan, Russia.
}

(date of receiving: February, 2018; date of acceptance: August, 2018)

\begin{abstract}
Russian derivative nouns with the meaning of a female person constitute a modification word-forming category of femininity and represent secondary nominations structurally and semantically related to the names of males. In the formation of nouns with the value of femininity, specific derivational suffixes are used, and the derivation process is often accompanied by morphological transformations of the producing basis. Mastering derivatives with the meaning of female persons presents considerable complexity for students from Iran, since the Persian language does not have a gender category and in most cases the same lexemes are used for the nomination of persons of both sexes. The article substantiates the necessity of studying nouns with the meaning of a female person by Iranian students mastering the Russian language; the structural and semantic parameters of the suffixal derivatives of nouns that form the word-formative category of femininity are given; The repertoire of derivational means serving this category is called; morphological phenomena accompanying the derivation process are considered, as well as exercises on modeling and decoding of such derivatives that contribute to the formation of the word-forming competence of students are offered.
\end{abstract}

Keywords: Derivational Category, Feminative, Derivative, Exercise, Modeling, Decoding.

1. E-mail: sannikova_st@mail.ru 


\title{
Изучение категории женскости иранскими студентами
}

\section{Санникова Наталия Юрьевна ${ }^{1}$}

Доцент, Астраханский государственный университет,

Астрахань, Россия.

(дата получения: февраль 2018 г.; дата принятия: август 2018 г.)

\begin{abstract}
Аннотация
Русские производные существительные со значением лица женского пола составляют модификационную словообразовательную категорию женскости и представляют собой вторичные номинации, структурно и семантически связанные с названиями лиц мужского пола. При образовании существительных со значением женскости используются специфические словообразовательные суффиксы, а процесс деривации нередко сопровождается морфонологическими преобразованиями производящей основы. Освоение дериватов со значением лиц женского пола представляет значительную сложность для студентов из Ирана, поскольку в персидском языке отсутствует категория рода и для номинации лиц обоих полов в большинстве случаев используютея одни и те же лексемы. В статье обосновывается необходимость изучения существительных со значением лица женского пола иранскими студентами, осваивающими русский язык; приводятся структурно-семантические параметры суффиксальных производных существительных, составляющих словообразовательную категорию женскости; называется репертуар деривационных средств, обслуживающих данную категорию; рассматриваются морфонологические явления, сопровождающие процесс деривации, а также предлагаются упражнения по моделированию и декодированию подобных дериватов, способствуюпие формированию словообразовательной компетенции обучающихся.
\end{abstract}

Ключевые слова: Словообразовательная Категория, Феминатив, Дериват, Упражнение, Моделирование, Декодирование.

1. E-mail: sannikova_st@mail.ru 


\section{Введение}

В российской лингводидактике уже стало общепризнанным положение о ведущей роли обучения русскому словообразованию для формирования коммуникативной компетенции иностранньх обучающихся. Как справедливо отмечает Л.В. Красильникова, «...без знания единиц русского словообразования, особенностей производного слова по сравнению с непроизводным невозможно рассматривать роль производных слов в речемыслительной деятельности говорящего, решать коммуникативные задачи общения» (Красильникова 2015. 72).

Действительно, роль обучения словообразованию трудно переоценить, поскольку примерно $90 \%$ русских слов, имеющих различную частеречную принадлежность, являются производными. По словам Е.С. Кубряковой, «...словообразование, подобно грамматике, участвует самым непосредственным образом в создании объёмных классов слов, объединённых по определённому признаку, и в выражении этими словами определённых обобщённых значений» (Кубрякова 1988. 150).

Все производные слова, вне зависимости от их частеречной принадлежности, входят в определённую словообразовательную категорию, под которой понимается формально-семантическая схема «образования производных слов, принадлежащих к одной части речи, имеющих общее С3 (словообразовательное значение - Прим. Н.Ю.) и образованных одним и тем же способом словообразования) (Белякова 2007. 29). Так, например, производные имена существительные входят в словообразовательные категории наименований опредмеченных признаков и процессов, состояний, орудий и результатов деятельности, жилищ, лиц мужского пола и лиц женского пола, детёнышей и т.д.

Одной из самых многочисленных групп внутри производных имён существительных являются наименования лица. Причина исключительной 
многочисленности наименований лица определяется богатством системы русских деривационных аффиксов и разнообразием словообразовательных типов, а также особым положением суффиксальных существительных со значением лица, заключающемся в том, что они называют человека - субъекта всех социальных процессов, действий, изменений. Человек как персонифицированная единица многообразных общественных отношений не может не оказаться в центре внимания самих людей, для которых и существует язык - важнейшее средство человеческого общения. Наименования лица называют человека в его всевозможных отношениях к другим людям, к обществу в целом, к профессии, к общественной деятельности, к природе и т.д..

\section{Основная часть}

Русские производные со значением лица женского пола, составляющие модификационную словообразовательную категорию женскости, занимают особое место среди имён лиц, поскольку номинации лиц женского пола представляют собой вторичные номинации, структурно и семантически связанные с маскулинными названиями лиц.

Алеш Бранднер небезосновательно полагает, что главным признаком всех наименований лиц женского пола «является их зависимость от соответствующих мужских имен. Непосредственной производящей основой для образования женского варианта считается всегда основа существительного мужского рода, к которому присоединяется производящий формант» (Бранднер 2003. 15). Именно поэтому для понимания семантики «женских» наименований необходима определённая когнитивная база (уверенное владение производной лексикой, используемой в русском языке для обозначения лиц мужского пола по характерному признаку, по роду деятельности, взглядам, национальному признаку, производимому действию и 
т.д.), а также понимание механизма деривации и репертуара словообразовательных средств.

Известно, что существительные, составляющие словообразовательную категорию женскости, неоднородны по семантическим признакам, в связи с чем их можно разделить на две группы - наименования женщин и наименования самок, причём каждая из подгрупп в свою очередь тоже имеет дифференциальные семантические признаки (Санникова 2015. 552).

В первую семантическую группу включаются следующие наименования лиц женского пола: 1) женщина по профессии (например, ивея, географиня), 2) женщина по национальности или месту жительства (например, ереванка, кабулка), 3) женщина по социальной принадлежности или по социальному статусу (например, лимитчица, беженка), 4) женщина по идеологическим или религиозным взглядам, убеждениям, принадлежности к политической партии, организации (например, либералка, демократка) 5) женщина по чертам характера, интеллектуальным качествам (например, эрудитка, веселуика), 6) женщина по особенностям внешности (например, иатенка, толстячка), 7) женщина по пристрастиям, склонности, роду занятий (например, автомобилистка, собачница), 8) женщина-жена или женщина-дочь (например, супруга, виконтесса).

Ко второй семантической группе относятся выделяются следующие наименования лиц женского пола: 1) самка животного (например, тигрица, львица, ящерица, коика, сайгачиха, крокодилиха, слониха), 2) самка птицы (например, ворониха, орлица, ястребиха, горлинка, воробьиха), 3) самка насекомого (например, клопиха, комариха, тараканиха), самка рыбы (например, окуниха, ерииха, сазаниха, язиха).

Очевидно, что даже простое перечисление дериватов, входящих в словообразовательную категорию женскости, свидетельствует о высокой репрезентативности феминативов в современном русском языке и 
демонстрирует неоднородность используемых при деривации аффиксальных средств.

Как показывает наш опыт, освоение производной русской лексики со значением лиц женского пола представляет значительную сложность для иностранных студентов, изучающих русский язык. Следует отметить, что процесс усвоения феминативов студентами из разных стран обусловлен особенностями строения их родного языка. Так, например, для студентовславян русские феминативы не представляют особой сложности, поскольку, как отмечают исследователи, «...славянские языки располагают в целом сходной системой средств, служащих для образования наименований лиц женского пола по профессии, роду деятельности, должности, званию от базовых существительных мужского рода. Различия касаются конкретного инвентаря этих средств, особенностей сочетаемости с конкретными основами...» (Лешкова 2017. 170).

Для носителей же персидского языка процесс изучения модификационной словообразовательной категории женскости осложняется тем, что в персидском языке, как известно, отсутствует категория рода и поэтому для номинации лиц обоих полов в большинстве случаев используются одни и те же лексемы. Так, например, в персидском языке одинаково именуются

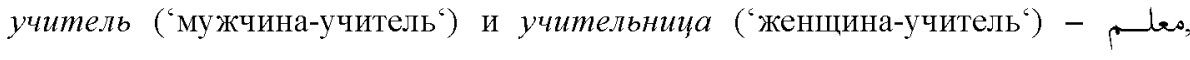
художник ('мужчина-художник') и художница ('женщина-художник') - نقـاش писатель и писательница - هنسئن продавеу ('мужчина-продавец') и

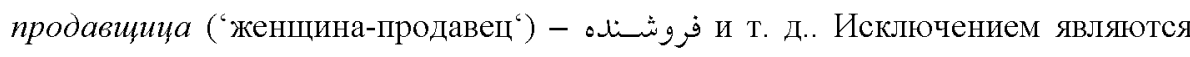
лишь отдельные обозначающие лиц слова, заимствованные из арабского языка, в которых гендерная дифференциация выражается окончанием

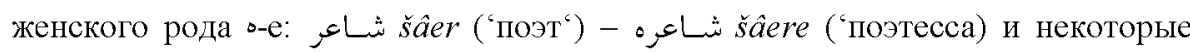
другие. 
Приступая к изучению лексики, называющей лиц женского пола, следует, прежде всего представить обучающимся сведения о механизме словопроизводства феминативов. При этом преподаватель должен наглядно продемонстрировать иранским студентам, что в процессе деривации существительных, называющих лиц женского пола, к производящей базе, в качестве которой выступают наименования лиц мужского пола, присоединяются специфические суффиксы, не только меняющие морфемную структуру слова, но и преобразующие его семантику, например: $n о э m+e c c(a)$ $\rightarrow$ поэтесса 'женщина-поэт', учитель + ниц(a) $\rightarrow$ учительница 'женщцинучитель', максималист + $(a) \rightarrow$ максималистка 'женщина-максималист', актёр $+u c(a) \rightarrow$ aктриса 'женщина-актёр' и т.п..

Чтобы не допускать ошибок при образовании и использовании существительных, именующих лиц женского пола, иранские студенты должны не только понимать деривационный механизм русского словообразования, но и прочно усвоить основные схемы построения производных слов данной словообразовательной категории, активно функционирующей в современном русском языке, а также владеть знаниями о морфемарии, представляющем собой перечень всех возможных словообразовательных средств, с помощью которых производятся подобные дериваты

Репертуар словообразовательной категории русских производных существительных со значением женскости представляет собой закрытый список, состоящий из следующих суффиксов: 1) -к(a) (абориген $+\kappa(a) \rightarrow$ аборигенка), 2)-ниц(a) (всадник + ниц(a) $\rightarrow$ всаднища), 3) -щии(а) (алиментщик + щиц $(a) \rightarrow$ алиментщица $), 4)-u(a)($ доктор $+u(a) \rightarrow$ докториа), 5) -j(a) $($ враль $+j(a) \rightarrow$ вралья), 6) -чии(a) (обидчик + чии $(a) \rightarrow$ обидчица), 7) -их(a) $($ повар $+u x(a) \rightarrow$ повариха), 8) -ии(a) (ангел $+u и(a) \rightarrow$ ангелица), 9) -ин(a/a) $($ биолог $+u н(я) \rightarrow$ биологиня), 10) -есс (a) $($ бард + есс $(a) \rightarrow$ бардесса), 11) -н(a) 
$($ дон $+\mu(a) \rightarrow$ донна), 12)-ис(a) (актёр $+u c(a) \rightarrow$ актриса), 13)-yx(a) (cтарик $+y x(a) \rightarrow$ старуха), 14) нулевой суффикс $($ cynруг $+\varnothing \rightarrow$ бупруга). В русской морфемике есть один уникальный суффикс -ад’j(a), с помощью которого образуется дериват попадья со значением «жена попа».

Думается, что немаловажной для иранских студентов является и информация о продуктивности названных суффиксов. Наиболее частотно дериваты, обозначающие лиц женского пола, образуются с помощью присоединения к основе маскулинного наименования суффикса $-\kappa(a)$, позволяющего номинировать лицо женского пола по роду занятий, по принадлежности к какой-нибудь профессии, по характерному действию, по национальному и территориальному признаку, по идейным взглядам, например: окулист $\rightarrow$ окулистка, оркестрант $\rightarrow$ оркестрантка, операционист $\rightarrow$ операционистка, литовеи $\rightarrow$ литовка, дагестанеи $\rightarrow$ дагестанка, комсомолец $\rightarrow$ комсомолка, партиеч $\rightarrow$ партийка.

Характерно, что названия лиц женского пола с суффиксом -к(a) могут быть образованы от следующих типов «мужских» существительных:

а) простых, например: цыган $\rightarrow$ цыганка, псих $\rightarrow$ психичка,

б) имеющих суффикс -ист, например: джазист $\rightarrow$ жазистка, журналист $\rightarrow$ журналистка,

в) имеющих суффикс -ец, который при деривации всегда усекается, например: немец $\rightarrow$ немка, многоборец $\rightarrow$ многборка, :

г) имеющих суффикс -ин или -анин, которые также подвергаются усечению, например: гражданин $\rightarrow$ гражданка, мусульманин $\rightarrow$ мусульманка, волжсанин $\rightarrow$ волжанка, христианин $\rightarrow$ христианка,

д) имеющих суффикс -ик, например: неврастеник $\rightarrow$ неврастеничка, фанатик $\rightarrow$ фанатичка,

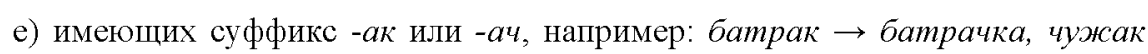
$\rightarrow$ чужачка, 
ж) имеющих суффиксы -ич, -ит, -ат, -анm/-енm, -смен, -ии, -тяй, -ей, например: суннит $\rightarrow$ суннитка, ииит $\rightarrow$ ииитка, эрудит $\rightarrow$ эрудитка, акробат $\rightarrow$ акробатка, арестант $\rightarrow$ арестантка, клиент $\rightarrow$ клиентка, рекордсмен $\rightarrow$ рекордсменка, слюнтяй $\rightarrow$ слюнтяйка, чародей $\rightarrow$ чародейка,

3) имеющих суффиксы -ер/-онер/-ир, -apb, -aн, например: изувер $\rightarrow$ изуверка, акционер $\rightarrow$ акционерка, пассажир $\rightarrow$ пассажирка, бунтарь $\rightarrow$ бунтарка,

и) сложными существительными с нулевым суффиксом, например: верхогляд $\rightarrow$ верхоглядка,

к) сложными существительными с иноязычными компонентами -ман и крат, например: клептоман $\rightarrow$ клептоманка, бюрократ $\rightarrow$ бюоократка, демократ $\rightarrow$ демократка.

Следующую по продуктивности позицию после суффикса -к(a) занимает суффикс -иц(a), с помощью которого образуются существительные, обозначающие лиц женского пола по профессии, месту работы, роду занятий, качеству, свойству и т.д.. Такие существительные мотивируются следующими существительными, обозначающими лиц мужского пола:

a) простыми, например: мастер $\rightarrow$ мастерица,

б) с суффиксами -ец или -леи, например: домовладелец $\rightarrow$ домовладелица, умелец $\rightarrow$ умелица,

в) с суффиксами -ик, -ник, -ищик, -чик, например: дачник $\rightarrow$ дачница, дольщик $\rightarrow$ дольцица, добытчик $\rightarrow$ добытчица,

г) с суффиксом -тель, например: грабитель $\rightarrow$ грабительница, даритель $\rightarrow$ дарительница.

Третья по продуктивности позиция принадлежит суффиксу -есc(a), который образует наименования лиц женского пола по титулу или по профессии (зачастую творческого, артистического и спортивного характера), 
причём данный суффикс всегда присоединяется к простым существительным мужского рода, например: патрон $\rightarrow$ патронесса, прини $\rightarrow$ принцесса, клоун $\rightarrow$ клоунесса, поэт $\rightarrow$ поэтесса

Далее следует ещё менее продуктивный суффикс -ис (a), с помощью которого названия лиц женского пола создаются на базе существительных мужского рода с суффиксами -ор или -ёр, например: актёр $\rightarrow$ актриса, директор $\rightarrow$ директриса.

Относительно небольшое количество существительных, относящихся к словообразовательной категории женскости, образуются в современном русском языке с помощью суффикса -ин(я), -ын(я) от простых существительных, номинирующих лиц мужского пола по различным признакам, например: бог $\rightarrow$ богиня, гериог $\rightarrow$ гериогиня, раб $\rightarrow$ рабыня, монах $\rightarrow$ монахиня.

Конечно, на продвинутом этапе изучения русского языка иранскими студентами им можно презентовать и малопродуктивные и непродуктивные суффиксы, с помощью которых в современном русском языке создаются лишь единичные производные наименования лиц женского пола. К таким суффиксам, например, относится суффикс -b(я). Следует отметить, что продуктивность этого суффикса ограничивается сферой употребления. Дериваты, включающие его в свой морфемный состав, чаще всего используются в повседневной разговорной речи, например: брехун $\rightarrow$ брехунья, игрун $\rightarrow$ игрунья, ползун $\rightarrow$ ползунья, храпун $\rightarrow$ храпунья, пискун $\rightarrow$ пискунья, молчун $\rightarrow$ молчунья, скакун $\rightarrow$ скакунья, бегун $\rightarrow$ бегунья, хлопотун $\rightarrow$ хлопотунья, врун $\rightarrow$ врунья. Во всех случаях названный суффикс присоединяется к основе существительного мужского рода, называющих лиц по совершаемым ими действиям.

Все названные выше, вне зависимости от их продуктивности, суффиксы не имеют стилистической маркированности, в отличие от стилистически 
окрашенных суффиксов, присоединение которых к производящей базе сопровождается иронично-снисходительными или пренебрежительными коннотациями. Думается, что иранским студентам интересно будет узнать, что ряд суффиксов привносит в названия лиц женского пола дополнительные наращения семантики, которые демонстрируют специфическое восприятие человеком, использующим подобные номинации, называемых им лиц женского пола. К таким женщинам отношение, по меньшей мере, несерьёзное.

Прежде всего, это чаще всего используемый для выражения подобного отношения стилистически маркированный суффикс -и(a), встречаемый, например, в словах губернаториа (от губернатор), композиториа (от композитор), костюмериа (от костюмер), репетиториа (от репетитор), риелториа (от риелтор), комментаториа (от комментатор), музыкантиа (от музыкант), архитекториа (от архитектор), администраториа (от администратор), модельериа (от модельер).

Важно сообщить иранским студентам, что не все наименования лиц мужского пола способны стать производящими базами для феминативов с суффиксом -и( $a)$, а лишь такие, основа которых оканчивается:

a) на согласные $-p,-л,-н$, например: арендатор $\rightarrow$ арендаториа, новатор $\rightarrow$ новаториа, экзаменатор $\rightarrow$ экзаменаториа, кредитор $\rightarrow$ кредиториа, инспектор $\rightarrow$ инспекториа, великан $\rightarrow$ великаниа, библиотекарь $\rightarrow$ библиотекариа, бригадир $\rightarrow$ бригадириа, аптекарь $\rightarrow$ аптекариа, маляр $\rightarrow$ маляриа, бухгалтер $\rightarrow$ бухгалтериа, юбиляр $\rightarrow$ юбиляриа, опекун $\rightarrow$ опекуниа,

б) на сочетание -нm, например: регент $\rightarrow$ регентиа, агенm $\rightarrow$ агентиа,

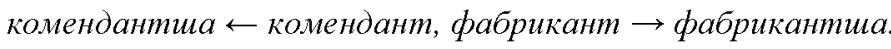

Также стилистически маркированным аффиксом, обслуживающим словообразовательную категорию наименования лиц женского пола является суффикс $-u x(a)$, с помощью которого в современном русском языке 
производятся соотносительные с существительными, называющих лиц мужского пола, «женские» наименования, например: врач $\rightarrow$ врачиха, сторож $\rightarrow$ сторожиха, гребеи $\rightarrow$ гребчиха, дворник $\rightarrow$ дворничиха. Отношение к таким лицам женского пола, занятым какой-либо деятельностью, как правило, насмешливо-несерьёзное, а порой и презрительно-уничижительное, за исключением, пожалуй, слов, называющих женщин, имеющих профессию, которая традиционно в России считается женской, например: повар $\rightarrow$ повариха, ткач $\rightarrow$ ткачиха.

Думается, что иронический оттенок этим наименованиям лиц женского пола придаёт аналогия с наименованиями самок животных типа барсук $\rightarrow$ барсучиха, аист $\rightarrow$ аистиха, слон $\rightarrow$ слониха

Помимо суффиксов - $и(a)$ и -ux(a), в этой сфере деривации функционирует также суффикс $-y x(a)$, который считается непродуктивным просторечным суффиксом, имеющим яркую экспрессивную окраску и вносящим в «женские» производные имена лиц оттенок пренебрежительности, например: толстуха (от толстяк).

Интересно, что суффиксы, переводящие семантику лиц мужского пола в «женскую» иногда проявляют несвойственные им признаки. Так, например, некоторые стилистически нейтральные суффиксы могут в некоторых случаях образовывать слова с отрицательной (иронично-снисходительной) оценкой, как, например, произошло с дериватом геологиня (от геолог). И наоборот, стилистически сниженный суффикс -u(a) образует некоторые стилистически нейтральные слова, например, соавториа (от соавтор).

Говоря о стилистических отличиях «мужских» и «женских» номинаций лиц, необходимо также обратить внимание студентов на тот факт, что суффикс -и(a), прежде позволявший назвать лицо женского пола как супругу какоголибо лица, в современном русском языке утратил такую функцию. В настоящее время отчётливо наблюдается тенденция утраты окраски 
разговорности у производных слов, в морфемную структуру которых включается названный суффикс, в результате чего слова на -u(a) активно используется в разговорной речи при номинации женщины по роду деятельности или характерному признаку, например: бригадир - бригадириа, командир - командириа, генерал - генеральша, бармен - бармениа, почтальон- почтальониа, автор - авториа.

Необходимо обратить внимание иранских студентов и на тот факт, что многие наименования лиц женского пола, образованные от маскулинных имён существительных и имеющие стилистическую маркированность, относятся к лексике разговорного стиля речи. Так, например, слова типа директриса, математичка, врачиха не являются официальными наименования лиц женского пола по профессии, а используются только в живой разговорной речи. Знание этой особенности феминативов позволит иранским обучающимся избежать ошибок в письменной речи, обслуживающий официально-деловой стиль.

Работая над обучением иранских студентов производной лексике со значением женскости, нельзя обойти вниманием и значительный пласт дериватов, именующих самок животных, птиц, насекомых, рыб. В современном русском языке наименования самок, как и лиц женского пола, образуются от основ существительных мужского рода со значением «самец», например: верблюд $\rightarrow$ верблюдица, бегемот $\rightarrow$ бегемотиха, голубь $\rightarrow$ голубица, олень $\rightarrow$ олениха, сайгак $\rightarrow$ сайгачиха, медеедь $\rightarrow$ медведица, лев $\rightarrow$ львица, комар $\rightarrow$ комариха, заяи $\rightarrow$ зайчиха, кот $\rightarrow$ коика

Следует сообщить обучающимся и тот факт, что в современном русском языке имеется ряд специфичных суффиксов, посредством которых образуются имена существительные, обозначающие названия животных. Наиболее употребительными из них являются суффиксы женского рода -ица, -иха, причем с суффиксом -иџа встречаются: 
а) общевидовые названия (например, мокрица, лисица, куница, курица, ящерица, синица),

б) наименования самок животных (медведица, верблюдица, кобылица, львица).

Наиболее частотно названия самок животных образуются посредством суффиксов -их(а) и -иц(a), например: зайчиха, слониха, воробьиха, тигрица, львица и т.п.. В основном эти образования на -иџа, -иха имеюо ударение на суффиксе (мокрича, слониха). Ударение на основе имеют лишь слова, например: я́щерица, медве́дица, верблю́дица. Остальные же суффиксы менее продуктивны в сфере производства наименования самок.

Обычно наименования самок животных производятся от соотносительных наименований мужского рода: медведь - медведица, лев - львица, зали зайчиха, курица (ср. устаревшее слово кур), яцерица (ср. название доисторического животного ящер). Однако ряд наименований самок не имеет параллельных форм самцов, например: кобылица (мужской род - жеребец), курица (мужской род - петух), овца (мужской род - баран). кроме того, есть отдельные пары «самец» - «самка», в которых производящим, напротив, является наименование самки, например: коза $\rightarrow$ козёл. Подобные словообразовательные пары требуют дополнительных комментариев преподавателя.

Как представляется, приведённая выше информация позволит иностранным студентам, изучающим русский язык, правильно моделировать и декодировать производные слова, обозначающие лиц женского пола, адекватно интерпретировать и использовать в процессе коммуникации с носителями русского языка.

Однако думается, что для иранских студентов простое усвоение перечня «женских» суффиксов и их стилистических особенностей не упростит задачу по моделированию или декодированию производных существительных, 
входящих в словообразовательную категорию женскости, а, скорее, напротив, вызовет когнитивный диссонанс в связи со значительным объёмом подобной информации. Как показывает наша практика, предъявление полного морфемария возможно только на заключительном этапе обучения лексике со значением женскости. При вводе суффиксов и формировании навыка конструирования и «расшифровки» дериватов необходимо руководствоваться принципами постепенности, необходимости и достаточности и предъявлять теоретические сведения дозированно.

На занятиях по русскому языку иранским студентам следует предлагать выполнение ряда специальных упражнений по моделированию суффиксальных дериватов, называющих лиц женского пола, и декодированию семантики феминативных существительных, созданных по конкретным словообразовательным моделям.

Приведём в качестве примеров некоторые типы заданий, которые используются нами в ходе преподавания русского языка студентам, приехавшим на учёбу из Ирана.

Упражнение 1. Образуйте наименования лиц женского пола от наименования лии по профессии и роду деятельности: стюард - стюардесса, преподаватель - ..., волейболист - .., учитель - .., родитель - ..., соперник .., спортсмен - .., лётчик - .., руководитель - ., повар - .., жсурналист .., куплетист - .., иахматист - .., переговорицк - .., помоцник - .., любитель - .., воспитатель - .., детективщиик - .., танцовщик - .., заказчик $-\ldots$, naиueнm...-

Важно помнить, что при выполнении подобных заданий преподаватель должен обращать внимание иранских студентов на морфонологические преобразования производящей базы, среди которых наиболее частотными бывают суффиксальные усечения, например: обидиик обидчица, индивидуальщщк - индивидуальщица, проводицк - проводница, спорщик - 
спорчица, переводиик - переводчица, закройщик - закройщуица, убориик убориция, режламщик - рекламичица и т.П..

Кроме того, подбирая языковой материал для подобного типа заданий, преподаватель должен учитывать факт наличия в русском языке синонимичных суффиксов, обслуживающих словообразовательную категорию женскости, и не только предъявлять обучающимся перечень деривационных морфем, но и снабжать сведениями о частотности суффиксов. Представляется целесообразным при выполнении заданий по моделированию русских дериватов со значением лица женского пола сгруппировывать производящие базы по словообразовательным типам, в соответствии с которыми к наименованиям лиц мужского пола присоединяется какой-либо конкретный суффикс

Будет нелишним приводить в качестве образцов словообразовательные модели, ориентируясь на которые иранские студенты смогут безошибочно «собирать» из предложенных преподавателем производящих баз и деривационных аффиксов производные слова.

Необходимо также указывать студентам на отдельные случаи несоответствия значения производных слов в парах типа маиинист маиинистка и особо отмечать отсутствие пары по гендерному признаку у слов типа маникюриа.

Упражнение 2. Образуйте наименования лищ женского пола от наименования лиц по национальности или по месту рождения и/или проживания: Англия - англичанин - англичанка, Таджикистан - таджиктаджсичка, Африка - африканец - .., Россия - россиянин - .., Астрахань астраханец - .., Москва - москвич - .., Иран - иранеч - .., Вьетнам вьетнамеи - ..., Китай - китаеи - .., Азербайджан - азербайджанеи - ..., Испания - испанец-..., Япония - японеч - ... . 
При выполнении заданий по моделированию дериватов, входящий в словообразовательную категорию женскости, преподавателю необходимо предоставить в распоряжение иранских студентов справочную информацию о наиболее частотных морфонологических преобразованиях производящих баз, что проявляется, прежде всего, в чередованиях согласных морфонем на стыке

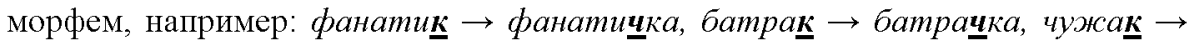

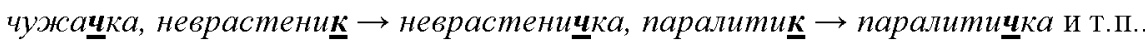

Следует также заметить, что во многих русских производных, называющих лиц мужского и женского пола, помимо чередований согласных, наличествуют интерфиксы, то есть асемантические межморфемные вставки, служацие устранению неблагозвучия при производстве дериватов, например: Конго конголезеч - конголезка, Америка - американеи - американка, Сочи -сочицеи

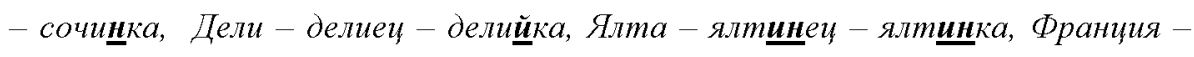
француз - франиуженка, Перу - перу쁘ец - перуанка, Италия - итальянец итальянка, Греция - грек-гречанка.

Задания, связанные с освоением феминативов, могут быть направлены также на закрепление навыков согласования слов в словосочетаниях, что немаловажно для выработки языковой компетенции иностранных обучающихся. Как известно, значительно количество ошибок в письменной и устной речи иностранцев связана с интерференцией родного языка. Так, например, для англоговорящих обучающихся трудным является употребление прилагательного перед существительным и их согласование. Для иранских студентов, в родном языке которых отсутствует категория рода, упражнения на согласование имён прилагательных с существительными, обозначающими наименования лиц мужского и женского рода, также представляет значительную сложность.

Упражнение 3. Согласуйте имена существительные и имена прилагательные: старый уцитель - старая учительница, знаком... продавеи - знаком... продавщзица, известн... художник - известн... художница, 
франиузск.. иккольник - франиузск... икольница, пакистанск... писатель пакистанск... писательница, популярн ... певец - популярн... певица, анлийск... король - английск... королева, юн... поэт -юн... поэтесса, отважн... ичиркачотвважн... циркачка, умел... сбориик - умел.. сборицца, настойчив... очередник - настойчив... очередница, способн.. студент - способнал студентка, немеик... спортсмен - немецк... спортсменка, истин... мусульманин - истин... мусульманка, иранск... преподаватель - иранск... преподавательница, интересн... собеседник - интересная собеседница, близк... родственник - близк... родственница, вдумчив... читатель вдумчив... читательница, важн... покровитель - важн... покровительница.

Хорошо зарекомендовали себя упражнения, в ходе которых студенты декодируют дериваты с применением формулы толкования. Следует отметить, что в лингводидактике упражнения, в ходе выполнения которых обучающимся приходится самостоятельно устанавливать значения незнакомых им слов с опорой на формулу толкования, признаются весьма эффективными, поскольку такие задания способствуют формированию навыка прогнозирования значения неизвестного деривата и развитию лингвистической догадки, устранению потенциальных коммуникативных рассогласований.

Упражнение 4. Oпределите значение производных наименований лиц, используя формулу толкования «та, которая является жсенциной-..»: шахматистка - та, которая является женциной-цахматистом; любительница - .., скандалист - .., арлянка - .., клеветница - .., иранка .., искательница - .., дипломантка - ., баскетболистка - .., магистрантка - ..., скрипачка - , иностранка - .., бельгийка - .., пианистка - .., адвокатесса - .., жсрица - .., эрудит - .., воспитательница - .., аспирантка - .., кормилица - .., журналистка - .., пегеранка - .., париклахериа - ..., расхитительница - .., интеллектуалка - .., авантюристка - .., оркестрантка - .., романист - .., злодейка - ... . 
Помимо названных выше типов заданий, иранским студентам можно предложить упражнения на моделирование наименований самок животных, птиц, рыб, базирующиеся на полученных обучающимися ранее теоретических сведениях об общих значениях феминативов, знании механизма деривации таких производных суффиксальных имён существительных, репертуара деривационных средств, а также особенностей словопроизводственного процесса.

Упражнение 5. Как называется самка животных, птиц, рыб? Лев львица, тигр - .., леопард - .., слон - .., гепард - ., орёл - .., кориун - .., ястреб - .., воробей - ., окунь - ., сазан - ., ёри - ., тюлень - ., морж..., кот $-\ldots$, олень $-\ldots$.

Весьма эффективны на занятиях задания на конструирование дериватов со значением лиц женского пола по аналогии с уже знакомыми студентам словообразовательными моделями.

Упражснение 6. Как называется женщиина, которая родилась или живёт в названной стране или городе? Аргентина - аргентинка, Абадан - ..., Венесуэла - ..., Волгоград - ..., Дели - .., Австрия - ..., Палестина - ..., Герлания - .., Венгрия - .., Хабаровск - .., Мазандаран - .., Хамадан - ... Перу - .., Португалия - .., ПГираз - ... , Камбоджа - ...

\section{Зак.лючение}

Практика показывает, что комплекс приведённых упражнений не только развивает навыки словообразовательного моделирования и декодирования зачастую агнонимичной лексики, но и в целом формирует словообразовательную компетентность, без которой, как представляется, невозможно прочное и осознанное владение русским языком. Таким образом, изучение суффиксальных производных феминативных существительных может способствовать развитию коммуникативной компетенции иранских студентов. 


\section{Литература}

1- Бранднер Алеш (Aleš Brandner) (2003). Особенности выражения категории рода у одуиевлённых суцествительных в русском и чеиском языках / Sborník prací Filosofické fakulty Brne`ské university. Studia minora Facultatis Philosophicae Universitatis Brunensis. Series linguistica Brunensi. A51, 2003. - C. $13-24$.

2- Белякова Г.В. (2007). Словообразовательная категория суффиксальньтх локативных существительных в современном русском языке. Астрахань, Издательский дом «Астраханский университет». $170 \mathrm{c}$.

3- Красильникова Л.В. (2015). Лингводидактические аспекты описания русского языка иностранным филологам на современном этапе преподавания РКИ / Вестник РУДН. Серия «Русский и иностранный языки и методика их преподавания». - № 4. - С. 69-82.

4- Кубрякова Е.С. (1988). Роль словообразования в формировании языковой картины мира // Роль человеческого фактора в языке: Язык и картина мира / Б.А. Серебренников, Е.С. Кубрякова, В.И. Постовалова и др. М., Изд-во «Наука». $-216 \mathrm{c}$.

5- Лешкова О.О. (2017). Новъе явления в категории феминативов (на материале современного польского языка) / Язык, сознание, коммуникация: Сб. статей / Отв. ред. В.В. Красных, А.И. Изотов. Изд-во «МАКС Пресс», - Вып. 55. - С. $169-178$.

6- Санникова Н.Ю. (2015). Семантизация суцествительных NOMINA FEMININA на занятиях РКИ / Слово. Грамматика. Речь. Нзд-во «МАКС Пресе», № XVI. - C. 551-554.

\section{Bibliography}

1- Brandner Alesh (Aleš Brandner) (2003). Osobennosti vyrazhenija kategorii roda u odushevljonnyh sushhestvitel'nyh v russkom i cheshskom jazykah / Sborník prací Filosofické fakulty Brne ské university. Studia minora Facultatis Philosophicae Universitatis Brunensis. Series linguistica Brunensi. A51, 2003. - S. 13-24.

2- Beljakova G.V. (2007). Slovoobrazovatel'naja kategorija suffiksal'nyh lokativnyh sushhestvitel'nyh $v$ sovremennom russkom jazyke. Astrahan', Izdatel'skij dom «Astrahanskij universitet». $170 \mathrm{~s}$.

3- Krasil'nikova L.V. (2015). Lingvodidakticheskie aspekty opisanija russkogo jazyka inostrannym filologam na sovremennom jetape prepodavanija RKI / Vestnik RUDN. Serija «Russkij i inostrannyj jazyki i metodika ih prepodavanija». - № 4. S. $69-82$. 
4- Kubrjakova E.S. (1988). Rol' slovoobrazovanija v formirovanii jazykovoj kartiny mira // Rol' chelovecheskogo faktora $v$ jazyke: Jazyk $i$ kartina mira / B.A. Serebrennikov, E.S. Kubrjakova, V.I. Postovalova i dr. M., Izd-vo «Nauka». - 216 s.

5- Leshkova O.O. (2017). Novye javlenija v kategorii feminativov (na materiale sovremennogo pol'skogo jazyka) /Jazyk, soznanie, kommunikacija: Sb. statej / Otv. red. V.V. Krasnyh, A.I. Izotov. Izd-vo «MAKS Press», - Vyp. 55. - S. 169-178.

6- Sannikova N.Ju. (2015). Semantizacija sushhestvitel'nyh NOMINA FEMININA na zanjatijah RKI / Slovo. Grammatika. Rech'. Izd-vo «MAKS Press», № XVI. - S. $551-554$.

\section{HOW TO CITE THIS ARTICLE}

Sannikova Nataliya Yurevna (2018). Studying the Category of Femininity by Iranian Students. Issledovatel'skiy zhurnal musskogo yazyka i literatury. 12(2):pp: 187-207

DOI: $10.29252 /$ iarll.12.187

URL: http://journaliarll.ir/article-1-149-en.html

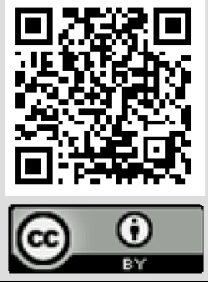




\title{
يادگيرى مقولهُ مؤنث زبان روسى توسط دانشجويان ايرانى
}

\author{
ناتاليا يورى يونا مانّى كورا' \\ دانشيار دانشخاه دولتى آستراخان، \\ آستراخان، روسيه.

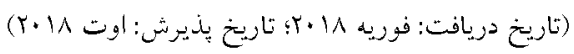

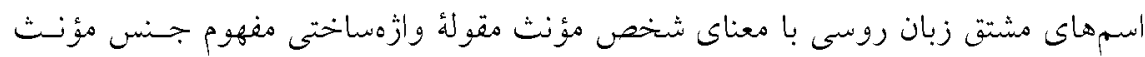

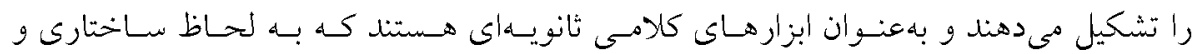

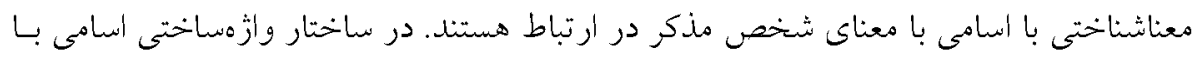

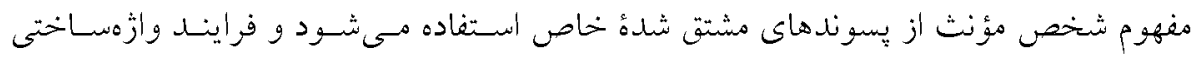

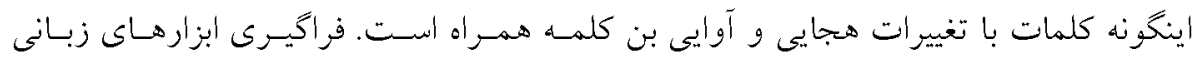

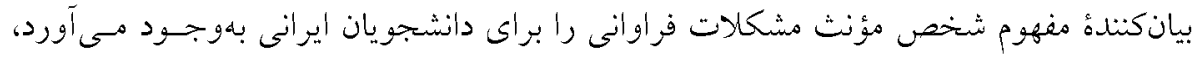

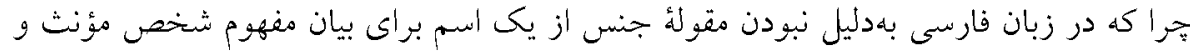

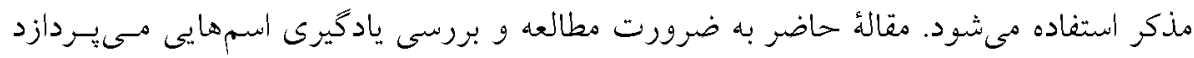

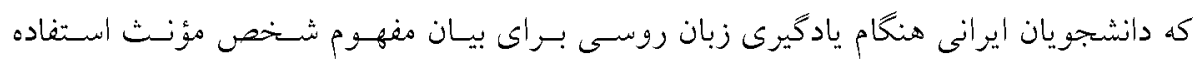

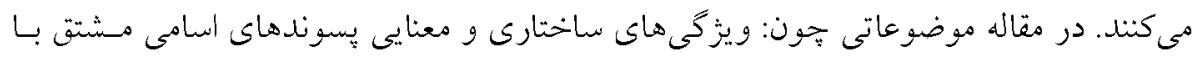

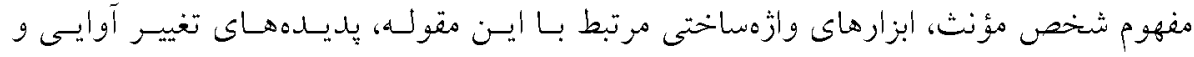

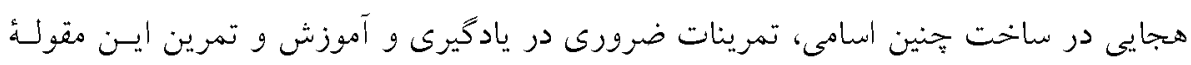

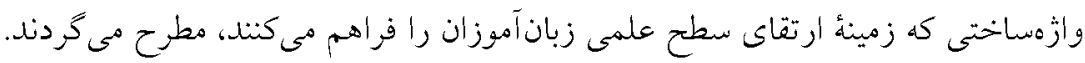

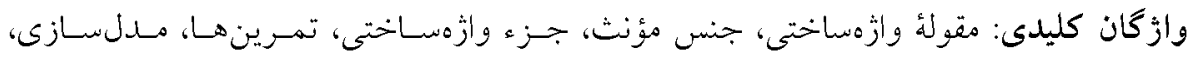

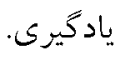

